\title{
Social learning by whom? Assessing gendered opportunities for participation and social learning in collaborative forest governance
}

\author{
Felicitas Egunyu ${ }^{1}$ and Maureen G. Reed ${ }^{1}$
}

\begin{abstract}
Collaborative forest governance enables forest-based communities access to and management responsibilities for forestry resources. Researchers argue that processes that enable social learning have the potential to contribute to the sustainable management of forests by engaging local people, helping them identify their collective needs and gain access to resource entitlements, and encouraging them to learn about and implement different management options. Although there is considerable attention to gender in the literature on collaborative forestry, particularly in developing countries, there is relatively little attention to gender in the social learning literature. Furthermore, there is almost no attention to these issues in postindustrial countries. Our purpose was to better understand how gender affects social learning and collaborative forest governance in forest-based communities in Canada and Uganda. Results showed that most participants in both countries started engaging in collaborative forest governance with limited knowledge and learned as they participated in various activities. However, we found that social learning opportunities and outcomes were affected by gender; in addition, they were also affected by the values that people held, education, and literacy. We suggest that practitioners should consider gender and other axes of difference if they want to design collaborative forest governance initiatives that are both participatory and inclusive.
\end{abstract}

Key Words: collaborative forest management agreement; community forest; forest-based communities; gender; participation; social learning

\section{INTRODUCTION}

Collaborative forest governance, whereby communities work within a government policy framework to manage forestry resources, has emerged to involve stakeholders within forestadjacent communities to participate in, and benefit from, forestry activities that provide sustainable livelihood opportunities (Pagdee et al. 2006, Charnley and Poe 2007). Members of local communities are considered key participants because they can provide contextual knowledge about forest resources, they express diverse needs and values, and they are the direct beneficiaries of the resource or bear the direct costs of resource protection and use (Brown et al. 2008, Larson and Soto 2008). However, the involvement of communities is not sufficient; research in resource management has suggested that groups engaged in collective action must also engage in learning if collaborative arrangements are to provide those groups environmental, social, economic, and cultural benefits from lands and resources (Rist et al. 2007, McDougall et al. 2013a,b).

To date, we do not know much about how women and men engage learning processes that become available through collaborative forestry governance. However, forestry remains a resource sector in which opportunities for employment, decision making, and benefit sharing vary significantly for women and men (e.g., Reed 2003, 2008, Mai et al. 2011). As the platforms for participating in collaborative forest management are not equally accessible, it is reasonable to ask whether the opportunities for and outcomes of social learning are also variable. Despite these documented inequalities in forest management, there is almost no research explaining how learning processes are gendered. This is surprising because the literatures on social learning focus on conditions by which fair and effective deliberation can be achieved at the community level (see Rist et al. 2007). A very small number of exceptions have focused on how social learning in collaborative resource governance can improve outcomes for women and other disadvantaged groups (e.g., Wollenberg et al. 2001, McDougall et al. $2013 a, b)$.

In a study of participation in collaborative forest governance that we conducted in Uganda and Canada, we found that women and men reported that they took part in different activities, learned different lessons related to collaborative forest management, and experienced different sets of motivations, enablers, and constraints. We turned to literature on social learning in community-based natural resource management to help us interpret these findings. However, there is very little research that specifies who participates in activities that might encourage social learning and collective action. Instead, we found calls for more research. For example, Armitage et al. (2008:86) indicated a need for greater "consideration of the role of power and marginality among groups participating in the learning process." Their observations were emphatically endorsed by McDougall et al. (2013b) who suggested that prior to sharing benefits associated with collective resource entitlements, participants in collaborative forest governance may first need to learn about inequalities within their community. Their work was confirmed by Shaw and Kristjanson (2014) who found that gender asymmetries in "development" projects of the global South meant that women typically had fewer financial and other assets for adapting to environmental and social change, as well as fewer opportunities to contribute their knowledge to decision-making and governance processes. After conducting a review of nine participatory projects in agriculture, livelihood, and climate adaptation in developing countries, they concluded that focusing attention on socially differentiated groups can bring substantive knowledge into collaborative resource management settings, enhance adoption of new strategies, improve collective understanding of environmental conditions and government policies, and mobilize 
knowledge through underutilized networks. These insights led us to explicitly reconsider our data with a focus on how men and women got involved in social learning opportunities provided through collaborative forest governance in each setting.

Hence, our purpose is to document social learning experiences and outcomes of men and women engaged in collaborative forest governance. We address the following questions:

1. Through what activities did men and women gain access to social learning opportunities as they participated in collaborative forest governance?

2. What learning outcomes did men and women report when they engaged in collaborative forest governance?

3. What factors enabled, motivated, and constrained participation and social learning by women and men?

We address these questions by way of two case studies of collaborative forest governance in Canada and Uganda. Our aim is exploratory and illustrative, not comparative. We are not trying to generalize to all situations in postindustrial and developing countries, but rather to identify and highlight issues related to gender, participation, and social learning in collaborative forest management that have previously not been investigated. By doing so, we contribute to addressing the need raised by Armitage et al. $(2008,2011)$ for greater attention to power inequalities between actors in social learning processes. We proceed by reviewing literature related to gender, social learning, and collaborative forest governance and by developing an analytical framework for advancing a gender-based analysis of social learning in collaborative resource management. We describe our cases and the methods used and present our results and discussion in relation to the research questions, drawing attention to the effects of gender and other categories of social differentiation on social learning and collaborative forest governance.

\section{LITERATURE REVIEW AND ANALYTICAL FRAMEWORK}

\section{Gender and social learning}

Gender refers to differences between males and females that are socially and culturally influenced. Although biological sex is usually established at birth, feminists contend that we become masculine or feminine through a combination of biologically determined sex differences and socially influenced characteristics (Mosse 1993, Nesmith and Wright 1995). For example, although men, on average, are larger and stronger than women, men's greater physical strength is reinforced from a young age, as boys have traditionally been encouraged to engage in active sports and other forms of physical activities, whereas girls have traditionally been encouraged to develop their fine-motor and nurturing skills. These expectations and attributes are then carried forward as children grow up, affecting their life chances such as opportunities for employment, social expectations of behavior, roles in society, and relations in households and communities. Although such expectations are not fixed in time and space, gendered norms within cultural contexts have remained remarkably resistant to fundamental social change over several generations.

Research reveals that the benefits of social learning and collaboration are not equally shared; they accrue to those who can participate effectively (McDermott 2009, McDougall et al. 2013a, Yadav et al. 2015). In both postindustrial and developing countries, researchers have demonstrated that participation in forestry decision making has been characterized by a gender order that privileges men's contributions to forestry (Reed 2010b), constrains women's participation in forestry management (Agarwal 2010, Mwangi et al. 2011), and ultimately contradicts the inclusive intentions of collaborative forest governance (e.g., Reed and Varghese 2007, Coulibaly-Lingani et al. 2011, McDougal et al. 2013a). Hence, we highlight gender as a central axis of social differentiation.

This is not to say that all men and women share the same experiences in collaborative forest governance. In both developing and postindustrial settings, participants' experiences will be tempered by social context, cultural and local norms, regulatory requirements, individual traits, and social constructs such as ability, age, ethnicity, wealth, class, and so on. Hence, not all women are disadvantaged relative to men, nor do all women necessarily share the same experiences. However, it does mean that it is relevant to ask how gender intersects with other social differences to influence access, opportunities, and outcomes associated with social learning and collaborative forestry governance. Gender-based analyses can also benefit those from disadvantaged groups. McDougall et al.'s $(2013 a, b)$ examination of social learning practices in community forestry in Nepal suggested that if such practices are located within safe and nested spaces for decision making, they can provide opportunities to meaningfully engage previously excluded participants, improve prospects for learning, and widen the range of benefits across community members. Their work focused on how social learning, in turn, improved the conditions and engagement of women and poorer participants, thereby encouraging us to be sensitive to the challenges that women and the poor face in trying to participate in collaborative forest governance.

Although it is tempting to believe that gender differences have been reduced in postindustrial countries, an international report focusing on forestry in Europe and North America concluded that "forestry ... has been generally regarded as an arena mainly for men's work, business and governance. Within organizations, from households to companies to authorities, a gendered organizational logic is at work which not only reproduces a structure of gender division but also, paradoxically, at the same time, makes gender invisible" (FAO 2006:1). More recently, Colfer (2013) surveyed cases internationally and documented a range of factors in postindustrial and developing countries that affect men's and women's understanding of, and involvement in, forest management, e.g., economic and household relations and informal and formal decision-making institutions.

\section{Challenges to understanding social learning in collaborative forest governance}

Three challenges related to learning in resource management settings more broadly are also evident in our study. The first challenge is determining the locus of learning: the individual or the group. Keen et al. (2005:4) define social learning as "collective action and reflection that takes place amongst both individuals and groups when they work to improve the management of the interrelationships between social and ecological systems." Keen et al.'s (2005) definition places emphasis on learning by 
"individuals and groups" as they participate in activities, although Reed et al.'s (2010) definition requires a "change in understanding that goes beyond the individual to become situated within wider social units or communities of practice" (our emphasis). Hence, we describe social learning as starting with the individual and then spreading to the group; learning outcomes may be both individual and collective and lead to collective action (Rist et al. 2007).

The second challenge is to find a way to accurately measure learning and attribute learning outcomes to specific interventions. We identified social learning outcomes according to eight variables and then classified these social learning outcomes according to three learning categories proposed by Lebel et al. (2010). According to Lebel et al. (2010), cognitive learning refers to learning factual knowledge and skills; normative learning includes changes in norms, values, and belief systems; and relational learning includes understanding other people's world views and builds trust. Although it may be relatively easy to attribute change in skill acquisition to a specific training activity or event(s), it becomes more difficult to attribute learning outcomes such as improvements in relationships to participation in a governance system. In our case, we asked study participants what they had learned and what changes had occurred in the community forest (CF) as a result of learning, an approach that has been used by scholars such as Brown et al. (2008), FernandezGimenez et al. (2008), and Brummel et al. (2010).

The third challenge is the potential to conflate participation with learning. Bull et al. (2008) and Reed et al. (2010) rightly point out that one need not participate to learn, and in addition, learning may not translate into specific action. Furthermore, learning can take place whether or not a platform is structured for that purpose. Muro and Jeffrey (2008), for example, rightly point out that learning can take place from conflictual settings as well as collaborative ones. However, it is also true that collaborative resource management platforms offer shared platforms for participation and for learning both individually and collectively. Researchers have documented that social learning occurs as people participate in collaborative resource management activities such as meetings, training, resource planning, resource extraction or harvesting, and monitoring (Brown et al. 2008, Cundill and Rodela 2012). People learn as they participate, and it may be artificial to separate the benefits of and barriers to participating and learning. Amid the murkiness suggested by these three challenges, how might one tease out gendered dimensions of learning and collaborative forest governance?

\section{A framework for assessing gendered dimensions of social learning in forest governance}

Our conceptualization of gender and social learning in collaborative forest governance suggests that to answer our research questions, we must pay attention to three elements: access to opportunities for learning, spaces of learning, and outcomes of learning.

\section{Element 1: gendered access to social learning platforms}

Accessibility to social learning opportunities is most closely related to the ability to participate. Access means having sufficient and appropriate opportunities to express one's choices and opinions and requires sufficient capacity including education, information, and logistical support to be able to understand and participate actively (Senecah 2004). Access is also strongly linked to capacity, which requires that participants have sufficient general and specific knowledge and skills to be effective participants and learners. There is considerable research showing that access to forestry-related activities and decision-making forums is not equally distributed. Many social groups such as itinerant workers, indigenous peoples, and women have tended to be excluded from forestry management and governance institutions (e.g., Agarwal 2010, Reed 2010a, b, Mwangi et al. 2011). Participation may be restricted by social/cultural norms and outright exclusion of particular groups (Agarwal 2010), power imbalances between men and women that fail to account for gender-specific needs (Reed 2010a, Mwangi et al. 2011), and lack of role models or social networks (Arora-Jonsson 2010, Sun et al. 2011). In excluding these actors from participation, such institutions exclude them from learning opportunities as well.

\section{Element 2: gendered spaces within learning platforms}

Our framework also draws attention to gendered spaces for learning. Harding's (1991) formative work on gendered knowledge suggests that within social settings, there are gendered cultures that separate women and men. For example, in Western contexts, men are drawn into masculinized spaces or cultures associated with the military and sports, whereas women are drawn into feminized spaces or cultures such as fashion or elementary education. Hayes and Flannery (2000:4) elaborate: "Women and men can be found in both cultures, but these cultures shape women's and men's experiences in different ways, giving them the opportunity to acquire different sorts of knowledge and abilities." Further, they suggest that these kinds of experiences also shape the interests and concerns of women and men when they are in similar situations. Women and men will likely take up different opportunities for learning, have different approaches to learning, and bring different kinds of knowledge and concerns into learning environments (Hayes and Flannery 2000). These differences may lead to social segregation, particularly if women and men take up different learning opportunities, and to spatial segregation if the activities occur in different places within the management setting. Our framework, therefore, considers whether platforms for learning become socially and spatially segregated.

\section{Element 3: gendered outcomes of learning platforms}

Participants may also take away different kinds of lessons from those learning environments. This is confirmed by one study related to collaboration in forest management in Canada that found that women tended to report communicative learning outcomes, whereas men tended to report more instrumental learning outcomes (Richardson et al. 2011). The framework draws attention to the outcomes described by women and men and interrogates for the motivations, enablers, and constraints that shape those outcomes.

\section{DESCRIPTION OF CASES}

We used qualitative research methodology involving a case study approach as described by Yin (2009). Two forestry organizations were studied, Harrop-Procter Community Forest (HPCF) in British Columbia, Canada, and Kapeeka Integrated Conservation Development Agency (KICODA) in Uganda. Both organizations had been in operation for at least seven years at the beginning of the research, thereby allowing time for outcomes to be realized and participants to understand their roles and to have something 
to reflect on. Although we used two cases, the study was not strictly comparative. The two cases were different and provided maximum variation (Yin 2009) enabling us to learn from settings in developed and developing countries. HPCF was established as one of the most "environmentally friendly" CFs in British Columbia, making it an illustrative and exemplary case (Yin 2009). KICODA was often mentioned by government officials, nongovernmental organization employees, and academic researchers as one of the most active community organizations at Budongo Forest, also making it an exemplary case (Yin 2009).

Using two cases in different settings, i.e., developed and developing countries, enabled us to examine similarities and differences in how forest-based communities in Canada and Uganda access forest benefits, participate in forest governance, and contribute to sustainable forest management. Thus, using two cases across different geographic and social contexts provided us with the opportunity to confirm and contest common assumptions and research findings. Although a single case in each country clearly does not represent all possibilities, as an exploratory study, our work can provide starting points for considering power and marginality in social learning as expressed by Armitage et al. $(2008,2011)$.

\section{Harrop-Procter Community Forest: Canada}

HPCF is located in the communities of Harrop and Procter, approximately $30 \mathrm{~km}$ northeast of Nelson in southwestern British Columbia. It covers 10,300 ha of Provincial Forest Crown land on the south shore of the west arm of Kootenay Lake. The HPCF community forest agreement with British Columbia Ministry of Forests was first signed in 1999 for a 5-year term. In 2008, HPCF received a 25 -year $\mathrm{CF}$ license negotiated with the province. HPCF is overseen by the Harrop-Procter Watershed Protection Society and the Harrop-Procter Community Cooperative. The society preceded the co-op. The society focuses attention on outreach and monitoring, whereas the co-op is the business arm of the CF. Harrop-Procter chose this cooperative model because it allowed public participation and maintained accountability (HPCF 2014). The co-op is run by an 11-member board, of which 5 are women; the society is run by a 9-member board, of which 5 are women. Both the co-op and the society hold annual general meetings that are open to the public, but voting is restricted to members.

During data collection, interviewees did not often differentiate between the co-op and the society. We will do the same and use HPCF or the CF to refer to both organizations. However, where necessary we will differentiate between the two organizations.

Kapeeka Integrated Conservation Development Agency: Uganda KICODA was registered in 2005 by the residents of Kapeeka village. Kapeeka is located along the southeastern border of Budongo Forest. Budongo Forest is located approximately 240 $\mathrm{km}$ northwest of Kampala. It covers $835 \mathrm{~km}^{2}$ and is the largest forest reserve in Uganda. It is divided into compartments, and KICODA manages one of the compartments that is adjacent to Kapeeka village.

The National Forest Authority (NFA) created the community forest management agreement (CFMA) as a means of enabling forest-adjacent communities to access forest resources, as well as assist with forest governance. To sign a CFMA, a forest-based community must first form a community-based organization (CBO) and then negotiate with NFA. The CFMA guidelines (NFA 2003) stipulate how the CBO should be set up and the required management processes. The guidelines also stipulate that at least one-third of the CBO executive committee should be female. Uganda also enshrined affirmative action for women and marginalized groups, i.e., the disabled, youth, elderly, and minority tribes, in the 1995 national constitution requiring an increase in the number of women in public and private offices. The CFMA lays out the rights and responsibilities of the signing body, and it covers a period of 10 years to match the period of a central forest reserve's management plan. The CFMA is renewable.

KICODA signed a CFMA because it gave the community legal access to forestry resources. The CFMA also lays out the mandate of KICODA, which can be summarized as follows: forest protection and conservation, development of alternative income sources, and raising public awareness. Membership in KICODA is individual and permanent. The membership fee is a onetime payment of 5000 Uganda shillings (equivalent to 2 Canadian dollars in 2013). To be a member, one has to be a resident of Kapeeka village. KICODA is run by a 12 -member executive committee made up of 6 men and 6 women as of April 2013. Like HPCF, KICODA also holds annual general meetings that are open to the public where voting is restricted to members.

\section{DATA COLLECTION AND ANALYSIS}

Data were collected by the lead author using interviews of local members of the collaborative, interviews of key persons in relevant government agencies and nongovernmental organizations, focus group meetings, and participant observations from January to July 2013 (Table 1). Participants for the personal interviews were identified using the snowball method starting with the leadership. At HPCF, it was the board members of the society and co-op, and at KICODA, it was the members of the executive committee. A semistructured interview guide was used, and all interviews were recorded with the consent of the interviewees. Each personal interview lasted about 1 hour at both locations. The same interview guide was used at both study sites. The interview questions were designed to obtain information on what activities people participated in, what they learned, how they learned, and whether they thought the CF was being effectively managed. Male and female translators were used at KICODA for interviewees who did not know English or who were not comfortable speaking English.

Table 1. Number of study participants by data collection method.

\begin{tabular}{lcccccccc}
\hline \hline & \multicolumn{3}{c}{$\begin{array}{c}\text { Harrop-Procter } \\
\text { Community Forest }\end{array}$} & & \multicolumn{3}{c}{$\begin{array}{c}\text { Kapeeka Integrated } \\
\text { Conservation } \\
\text { Development Agency }\end{array}$} \\
\cline { 2 - 3 } \cline { 6 - 8 } $\begin{array}{l}\text { Types of } \\
\text { Interviews }\end{array}$ & Female & Male & Total & Female & Male & Total \\
\hline $\begin{array}{l}\text { Personal } \\
\text { interviewees }\end{array}$ & 14 & 14 & 28 & 14 & 17 & 31 \\
$\begin{array}{l}\text { Focus group } \\
\text { participants } \\
\begin{array}{l}\text { Key person } \\
\text { interviews }\end{array}\end{array}$ & 6 & 5 & 11 & 10 & 13 & 23 \\
\hline
\end{tabular}


Focus group meetings were also used because they provided the opportunity for HPCF and KICODA members to interact and respond as a group, as well as confirm or refute personal interview findings. All personal interview participants were invited to the focus group meetings. At KICODA, all focus group participants had also participated in the personal interviews. At HPCF, four of the participants had not participated in the semistructured interviews but were members of HPCF and lived within HarropProcter. The focus group meetings were used to present and confirm preliminary findings from personal interviews. At KICODA, one mixed focus group was conducted in English, one all-male focus group was conducted in Lugbara and English, and the rest, i.e., one all-male and two all-female focus group meetings, were conducted in Swahili and English. Male and female translators were used for the all-male and all-female KICODA focus group meetings. One all-female focus group meeting and one mixed focus group meeting were held at HPCF. Key person interviews were also conducted. Key person interviews differed from personal interviews in that they targeted key persons from government and nongovernmental organizations for quality indepth interviews on collaborative forest governance.

Data were analyzed following a mix of inductive and deductive approaches whereby themes that emerged from analyzed data guided further analysis in conjunction with information from the reviewed literature (Miles and Huberman 1994). All interviews were transcribed verbatim, exported to NVivo, and coded using codes that were descriptive, explanatory, or in vivo, i.e., codes created from words or phrases used by interviewees. The codes were classified into themes that were then reviewed according to our analytical framework. In some cases, new themes emerged. Our analysis was not strictly comparative; we drew parallel lessons from each country setting.

\section{RESULTS}

\section{Activities and spaces for social learning}

Both KICODA and HPCF had almost equal numbers of males and females in their leadership. KICODA had almost equal numbers of males and females in its membership. As of January 2013, KICODA had 190 members, of whom 82 were women; the executive committee had 12 members, of whom half were women. As of January 2014, the co-op and the society had 137 and 37 members, respectively; membership information by gender was not provided, despite several direct requests. The co-op board had 11 directors, of whom 4 were women, and the society board had 9 directors, of whom 5 were women.

Participants identified 10 primary activities as mechanisms through which they participated in and learned about collaborative forest governance (Table 2). The most commonly reported activities in both cases were attending meetings and seminars and participating in business activities. HPCF interviewees reported that men and women were present in almost equal numbers. However, 3 female interviewees admitted to not attending meetings because their husbands were attending the meetings; in other words, they deferred to their husbands to participate for them. This was surprising because 3 women wrote the rules of association for the co-op, and 2 of the 4 authors for the $\mathrm{CF}$ proposal were women. However, over time, women withdrew from direct co-op activities.
It became apparent that although overall participation was relatively equal, the spaces of participation and learning were segregated. For example, some participants argued that men participated more than women, and the extent to which someone participated in an activity was determined by whether it was a "men's activity" or a “women's activity."In other words, the spaces of participation and learning were gender specific. For example, HPCF interviewees stated the following:

There is [sic] more men at the mill and employed to deal with the actual forest. (Interview, female participant)

The loggers were generally men and the people who started the botanicals were largely female. (Interview, male participant)

[There was a] stronger male perspective on the board. (Interview, female participant)

There were also some differences with regard to board preference; more women preferred to serve on the society board, which is responsible for forest and watershed protection, research, and public education, rather than on the co-op board, which is the business arm. So even though women were free to participate across all sites, women seemed to choose activities and spaces that have been more strongly associated with feminine roles and identities.

In KICODA, when asked whether there was any difference in participation between men and women, more than half of the respondents said men participate more in meetings and activities like forest patrols, beekeeping, and tree-seedling nursery preparation. However, people also said that women were found to participate more actively in tree-seedling nursery bed management, i.e., potting and watering, and obtaining/farming boundary and forest plots. The NFA allocated plots of land to KICODA members on the forest border. Plot owners were expected to cultivate food crops and grow trees. These activities also enabled them to serve as sentries along the forest border. Women expressed interest in these land allocations for growing food and planting trees, whereas men were more interested solely in planting trees.

Board membership at KICODA was not as clearly segregated by gender. One-half of KICODA's executive committee membership was female, and these women held key positions including secretary and treasurer. Most interviewees mentioned that the secretary, a female in her midtwenties and one of only two interviewees who were college graduates, was more knowledgeable about the organization than the chairman and his vice. The chairman himself referred some of the interview questions to her for confirmation. Although most KICODA participants described decisions as being equally beneficial to men and women with no particular group dominating decision making, they pointed out that the only license to commercially log was given to men. They also added that whenever there were study tours to other forest communities, more men than women traveled. Hence, opportunities to access and learn from these activities were also differentiated by gender.

In British Columbia, the villages of Harrop-Procter are attractive to urban "refugees" and retirees who also volunteer for various local organizations. HPCF has equal representation of men and 
Table 2. Participation in activities conducted by Harrop-Procter Community Forest and Kapeeka Integrated Conservation Development Agency that encouraged learning as mentioned by interviewees.

\begin{tabular}{|c|c|c|c|c|c|c|}
\hline \multirow[t]{2}{*}{ Activity Type } & \multicolumn{3}{|c|}{ Harrop-Procter Community Forest } & \multicolumn{3}{|c|}{ Kapeeka Integrated Conservation Development Agency } \\
\hline & Description of Activity & $\begin{array}{l}\text { Men } \\
\mathrm{N}=14\end{array}$ & $\begin{array}{l}\text { Women } \\
\mathrm{N}=14\end{array}$ & Description of Activity & $\begin{array}{l}\text { Men } \\
\mathrm{N}=17\end{array}$ & $\begin{array}{l}\text { Women } \\
\mathrm{N}=14\end{array}$ \\
\hline Meetings & $\begin{array}{l}\text { Board meetings, annual information } \\
\text { meeting, AGM, open house, information } \\
\text { series, forest management planning, AAC } \\
\text { revision. }\end{array}$ & 10 & 14 & $\begin{array}{l}\text { Executive committee meeting, women's } \\
\text { group meeting, workshops, planning } \\
\text { meetings. }\end{array}$ & 15 & 13 \\
\hline $\begin{array}{l}\text { Seminars/ } \\
\text { training }\end{array}$ & Board governance/business management. & 3 & 1 & $\begin{array}{l}\text { On-site and off-site training seminars on } \\
\text { forestry bylaws, patrolling, business } \\
\text { management, beekeeping, and so forth. }\end{array}$ & 19 & 11 \\
\hline $\begin{array}{l}\text { Forest } \\
\text { management }\end{array}$ & $\begin{array}{l}\text { Planning/operations, road construction, } \\
\text { clearing undergrowth/managing for forest } \\
\text { fires, replanting after logging. }\end{array}$ & 2 & 2 & $\begin{array}{l}\text { Enrichment planting, afforestation, } \\
\text { boundary planting, forest patrols, forest } \\
\text { boundary maintenance. }\end{array}$ & 24 & 18 \\
\hline Timber harvest & Logging, ongoing. & - & - & Logging, 1 license $\sim 4$ months long. & 2 & - \\
\hline NTFP harvest & $\begin{array}{l}\text { Individual/personal use: firewood, fruits, } \\
\text { mushrooms, craft material. }\end{array}$ & 10 & 14 & $\begin{array}{l}\text { Individual and contributes to family } \\
\text { livelihoods: firewood, thatching grass, } \\
\text { vegetables, craft materials, and so forth. }\end{array}$ & 17 & 14 \\
\hline NTFP business & Sunshine Bay Botanicals & - & 2 & $\mathrm{n} / \mathrm{a}$ & $\mathrm{n} / \mathrm{a}$ & $\mathrm{n} / \mathrm{a}$ \\
\hline Other forest use & $\begin{array}{l}\text { Recreation (e.g., fishing, skiing, mountain } \\
\text { biking), water source. }\end{array}$ & 15 & 21 & $\begin{array}{l}\text { Water source especially during dry } \\
\text { season. }\end{array}$ & 7 & 6 \\
\hline $\begin{array}{l}\text { Business } \\
\text { activities }\end{array}$ & $\begin{array}{l}\text { Organization business (i.e., mill/value added, } \\
\text { community forestry). }\end{array}$ & 8 & 2 & $\begin{array}{l}\text { Personal business (e.g., beekeeping, tree } \\
\text { planting, goat rearing, chili growing, } \\
\text { etc.). }\end{array}$ & 14 & 13 \\
\hline Networking & $\begin{array}{l}\text { Member of British Columbia Community } \\
\text { Forest Association, visited community } \\
\text { forests in BC, Russia, and Nepal to share } \\
\text { expertise. }\end{array}$ & 2 & 1 & $\begin{array}{l}\text { Visited other community-based } \\
\text { organizations in Rakai and Bushenyi to } \\
\text { learn from them. }\end{array}$ & 4 & 3 \\
\hline Hosting & $\begin{array}{l}\text { Elementary and high schools, postsecondary } \\
\text { institutes, university groups, and so forth. }\end{array}$ & 2 & 2 & $\begin{array}{l}\text { Hosted other groups to teach them about } \\
\text { collaborative forest management. }\end{array}$ & 7 & 3 \\
\hline Paid activities & $\begin{array}{l}\text { Employ forester, mill manager and workers, } \\
\text { office workers, timber harvesters, road } \\
\text { constructors, plus others as needed. }\end{array}$ & 5 & 3 & $\begin{array}{l}\text { Access National Forest Authority } \\
\text { contracts (e.g., road construction). } \\
\text { KICODA is paid a portion of the } \\
\text { contract fees. }\end{array}$ & 3 & 0 \\
\hline $\begin{array}{l}\text { Research and } \\
\text { monitoring }\end{array}$ & $\begin{array}{l}\text { Conduction forest and community surveys, } \\
\text { collect weekly water samples. }\end{array}$ & 4 & 5 & $\mathrm{n} / \mathrm{a}$ & $\mathrm{n} / \mathrm{a}$ & $\mathrm{n} / \mathrm{a}$ \\
\hline Other activities & Held work bees and fund-raisers. & 4 & 9 & $\begin{array}{l}\text { Established } 3 \text { seedling nurseries, held } 1 \\
\text { fund-raiser, mobilized community to } \\
\text { access other funds. }\end{array}$ & 15 & 8 \\
\hline
\end{tabular}

women on the leadership body. However, interviewees reported that women were left out of some of the decision-making processes. An interviewee explained:

To a degree I think that there tends to be a lot of decision making, or discussion about decisions, like with any business I guess, it doesn't go on at the board table, it sort of goes on behind the scenes and it goes on among, you know, a group of men. And women aren't necessarily invited to those conversations because you know, because it is men at the workplace, it is male oriented work. (Interview, female participant)

We found that whereas women are allowed to participate and learn about forestry management, they were sometimes excluded from specific decision spaces and hence restricted from learning more about forest management decision making.

In addition, spaces for learning appeared to become gendered through self-selection. At Harrop-Procter, the project "Sunshine
Bay Botanicals," a certified organic herb and nontimber forest products (NTFPs) company, was established in the early years of the CF. The project ran from 2001 to 2007 . HPCF was able to obtain grants that were specifically for the NTFPs project. Although there were volunteers from HPCF, students were also hired to work on the project over the summers. When it was established, it required 2 full-time volunteers, several part-time volunteers, and students. Products from the project were sold in the community, in the nearby city of Nelson, and as far away as Toronto and the United States. Most project volunteers were female. During interviews, 7 men and 8 women talked about the project. However, it was only the female respondents who also described learning from it:

Women really liked the herbal business [Sunshine Bay Botanicals $]$... they did a social event last year, women like to participate in those things. So you will have them advertising or baking or organizing the baking or cooking or whatever so there are opportunities. Not as many as 
Table 3. What interviewees reported learning during forest governance.

\begin{tabular}{|c|c|c|c|c|c|c|}
\hline Variable & $\begin{array}{l}\text { Harrop-Procter Community Forest, } \\
\text { Canada }\end{array}$ & $\begin{array}{l}\text { Men } \\
\mathrm{N}=14\end{array}$ & $\begin{array}{l}\text { Women } \\
\mathrm{N}=14\end{array}$ & $\begin{array}{l}\text { Kapeeka Integrated Conservation } \\
\text { Development Agency, Uganda }\end{array}$ & $\begin{array}{l}\text { Men } \\
\mathrm{N}=17\end{array}$ & $\begin{array}{l}\text { Women } \\
\mathrm{N}=14\end{array}$ \\
\hline \multirow[t]{6}{*}{ Knowledge acquired } & Forest ecology & 5 & 9 & Collaborative forest management & 12 & 12 \\
\hline & $\begin{array}{l}\text { Community forestry/forest } \\
\text { management }\end{array}$ & 11 & 13 & Tree nursery setup and management & 10 & 7 \\
\hline & Board governance & 3 & 4 & Tree planting & 16 & 11 \\
\hline & $\begin{array}{l}\text { Nontimber forest products } \\
\text { management }\end{array}$ & - & 2 & Beekeeping & 14 & 7 \\
\hline & Business management & - & 4 & Small business management & 1 & 3 \\
\hline & $\begin{array}{l}\text { Proposal development and fund- } \\
\text { raising }\end{array}$ & - & 1 & Advocacy/lobbying politicians & 1 & 1 \\
\hline \multirow[t]{4}{*}{ Skills acquired } & Forest monitoring & - & 6 & Tree planting & 16 & 11 \\
\hline & Timber cruising & 1 & - & Beekeeping & 14 & 7 \\
\hline & & & & Forest patrolling & 4 & 0 \\
\hline & & & & Tree nursery setup and management & 10 & 7 \\
\hline Developed social skills & Communicating with the public & - & 1 & $\begin{array}{l}\text { Working with other similar } \\
\text { organizations }\end{array}$ & 1 & 1 \\
\hline $\begin{array}{l}\text { Action/activities } \\
\text { implemented }\end{array}$ & $\begin{array}{l}\text { Closure of a nonprofitable project } \\
\text { (Sunshine Bay Botanicals) }\end{array}$ & 1 & 1 & Forest patrol & 9 & 3 \\
\hline $\begin{array}{l}\text { Relationships } \\
\text { improved or developed }\end{array}$ & $\begin{array}{l}\text { Starting to develop good working } \\
\text { relationship with Ministry of Forests }\end{array}$ & - & 1 & Improved relationships with NFA & 1 & 1 \\
\hline Behavior changes & & & & $\begin{array}{l}\text { Changed behavior: no longer logging } \\
\text { illegally/reported illegal activities to } \\
\text { NFA }\end{array}$ & 3 & - \\
\hline $\begin{array}{l}\text { Changes to values/ } \\
\text { assumptions/ attitude }\end{array}$ & $\begin{array}{l}\text { Changed attitudes/assumptions } \\
\text { about loggers and "high volume" } \\
\text { logging }\end{array}$ & - & 1 & $\begin{array}{l}\text { Changed values about trees and } \\
\text { forests }\end{array}$ & 1 & - \\
\hline
\end{tabular}

Note: What people reported does not add up to the total number of interviewees because the question was open ended, and we reported the number of times an item was mentioned. NFA, National Forest Authority.

they used to be when we were doing the craft fairs and the herbs and ... there was a lot of opportunity for people that didn't have a real solid base of the whole operation to get really good at those things. (Female participant, HPCF)

Well I've learnt a lot from the botanicals... I learnt a lot there because they [herbs] were not from the forest. They were planted in fields. I learnt how to make-, how to dry them, how to harvest them, I mean it was a lot. (Female participant, HPCF)

And then also business wise I've learnt as much as well in so many things, the whole process of Sunshine Bay Botanicals and then having to pull the plug on it. (Female participant, HPCF)

Over time, however, the Sunshine Bay Botanicals project was viewed as very labor intensive and did not provide the kind of income that logging could. Hence, the co-op board considered this project a failure and cancelled it in 2007. This decision effectively cut out a key activity that involved women. Following cancellation of the project, some women chose to concentrate their volunteer efforts on the work of the society. Both in the establishment of the Sunshine Bay Botanicals project and in shifting their energies toward outreach and education, women occupied learning spaces that reproduced long-standing social norms about the appropriate roles of women in forestry (Reed 2003). By contrast, men remained active in, and learning about, business and decision making associated with logging, activities that have been traditionally male-dominated in Canada (Reed 2008, Reed and Davidson 2011).

\section{Gendered social learning outcomes during collaborative forest governance}

When asked to describe some of the things they had learned, people described acquiring knowledge about forest ecology, conservation, and management. They also learned how to manage a community organization and deal with government agencies. What they learned enabled them to become effective participants and also gave them standing in terms of their ability to contribute to governance. What was learned was similar between HPCF and KICODA (Table 3). For example, men and women in both the Canadian and the Ugandan cases were evenly split in learning about community forestry, forest management, and collaborative forest governances.

We found that the segregation of learning spaces eventually led to gendered social learning outcomes in what people reported. For example, in Uganda, men reported learning about forest patrols; some of them did that through formal training at Nyabyeya Forest College. By contrast, few women reported learning about forest patrols, and all who did learned on the job. This suggests that outcomes were linked to the spaces where women and men learned. In Canada, women reported learning about ecology and large (corporate) business management, whereas in Uganda, women reported learning about small (personal) business management. In Uganda, more men than women reported learning about beekeeping; two interviewees suggested that women were afraid of bees. 


\begin{abstract}
Motivators, enablers, or constraints to participation and learning during forest governance
\end{abstract}

Because we assumed that participating in activities provides forums for learning, participants were asked open-ended questions to identify factors that motivated, enabled, or constrained their participation in activities from which they learned. Table 4 indicates the number of times the motivators and enablers were mentioned by both HPCF and KICODA interviewees. Some participants listed more than one motivator or enabler. Contributing to/interest in a well-managed natural environment topped the overall list of participation motivators in both locations.

There were some differences between motivators by gender. For men, the most frequently mentioned motivator was the desire to contribute to a well-managed environment. For women, knowledge and skills acquisition and accessing resources were most frequently mentioned (Table 3 ). There were noticeable differences between study sites. For instance, more Ugandan women mentioned knowledge and skills acquisition as a participation motivator. All the women who mentioned contributing to the environment were Canadian. Canadian men and women harvested NTFPs and used the CF for recreation but did not view these as participation motivators. In Uganda, the creation of the forest reserve restricted access to NTFPs until the signing of the CFMA. This could explain why being able to access NTFPs was mentioned as a motivator by only Ugandan participants (16/31).

Interviewees were asked to describe what constrained their participation. Specifically, they were asked: What are some of the things that limit your participation? Table 5 provides information on the number of times a personal constraint was mentioned by interviewees. In addition, interviewees described or mentioned participation constraints that men and or women faced more generally; this information was provided in response to other interview questions or follow-up questions (Table 6).

Tables 5 and 6 provide very different information about participation constraints. Although 8 of 31 participants from Uganda stated they faced no constraints when asked about their own situation (Table 5), both men and women provided many additional constraints that women generally face (Table 6). It is possible that asking some women in the third person about participation constraints freed them to share about female participation constraints without necessarily admitting that they personally faced the same constraints. The fear of men was an important constraint identified in follow-up questions and reported in Table 6 but was never mentioned when participants were asked directly (Table 5). Having a young family and the timing of activities also emerged as important constraints when people spoke of "others" (Table 6).

According to Table 5, time was a constraint that was common to both men and women. The physical nature of some of the activities limited women's participation at both sites. For example, at HPCF, logging, road building, and working at the mill were activities that were seen to be physically demanding and had few female participants. In Uganda too, fewer women were involved in the work that was very physically demanding such as treeseedling nursery preparation. So whereas interviewees said that the level of participation in both organizations was equal between men and women, it was acknowledged that the physical nature of some of the activities restricted those activities to mostly men. Hence, women were less likely to learn to do physical jobs associated with forestry:

Going for patrols in the forest ... these ladies you cannot take them there ... these people who are doing illegal activities inside there, they are energetic, so you cannot take a lady. (Male participant, KICODA)

To make those [tree-seedling] nursery beds, women don't, they can't manage ... Because at first they begin to dig and plow; maybe they dig in some bad places whereby you need to uproot a tree like this. So that one a woman cannot manage. (Female participant, KICODA)

I don't see any reason why they couldn't be [women
working at themill]. Imean it's a fairly physical workload
and we have had a number of people coming and asking
if we have been hiring ... But no women have applied, at
least not directly, to the mill. I know most of our office
staff are women. I mean personally, I would have no
problems whatsoever having female workers down at the
mill. (Male participant, HPCF)

At HPCF, several women mentioned a lack of opportunities and, by implication, learning opportunities. Interestingly, women also mentioned stepping down from the board of directors because they felt they lacked the required skill set. For example, they described having skills to contribute when the CF was being established, but when it started concentrating on becoming a profitable logging and milling business, they felt they did not have the right skill set. One man in HPCF also admitted to not having the technical expertise in forestry, and thereby, he felt he was unable to participate in the CF's operations management.

Literacy seemed to be an important Ugandan constraint, particularly where meetings were conducted in English with no interpretation. Budongo Forest area is renowned for having people from different tribes; at least eight languages, i.e., Lunyoro, Lugbara, Kakwa, Ateso, Acholi, Jopadhola, Madi, and Lendu, were identified during data collection. In addition to these languages, English and Swahili were also spoken. Because of the large number of languages, meetings were sometimes conducted in English when visitors were around or during seminars. Some female interviewees said they felt left out during such meetings.

\section{DISCUSSION}

\section{Access and outcomes of participation and social learning in} collaborative forest governance

Our research confirmed that gender plays a role in access to and outcomes of participation and social learning in collaborative forest governance. For example, at HPCF, there were more men at the mill, logging, and constructing roads, whereas more women were involved in the NTFPs project, watershed protection activities, support, and administration. Although initially more women participated in the co-op board, it appears that as the board became more focused on logging and timber production, women dropped off. Hence, learning opportunities became spatially segregated. However, related research suggests that gender may not be the only dimension influencing opportunities 
Table 4. Participation motivators and enablers identified by interviewees.

\begin{tabular}{|c|c|c|c|c|c|}
\hline \multirow[t]{2}{*}{ Participation Motivators and Enablers } & \multicolumn{2}{|c|}{ Canada } & \multicolumn{2}{|c|}{ Uganda } & \multirow{2}{*}{$\begin{array}{l}\text { Total } \\
\mathrm{N}=59\end{array}$} \\
\hline & $\begin{array}{c}\text { Men } \\
\mathrm{N}=14\end{array}$ & $\begin{array}{l}\text { Women } \\
\mathrm{N}=14\end{array}$ & $\begin{array}{c}\text { Men } \\
\mathrm{N}=17\end{array}$ & $\begin{array}{l}\text { Women } \\
\mathrm{N}=14\end{array}$ & \\
\hline Contribute to/interested in well-managed environment (e.g., watershed, forest) & 5 & 7 & 7 & 0 & 19 \\
\hline Access/obtain resources (e.g., NTFPs), benefits (e.g., plots for cultivation) & 0 & 0 & 7 & 9 & 16 \\
\hline Acquire knowledge and skills (i.e., learning) & 0 & 2 & 5 & 5 & 12 \\
\hline Belong to and work with a community/cooperative group & 7 & 2 & 1 & 1 & 11 \\
\hline Livelihood based on forestry/have knowledge or experience & 1 & 4 & 0 & 0 & 5 \\
\hline Interest in specific activity/interesting activities (e.g., nursery bed for KICODA) & 0 & 0 & 0 & 2 & 2 \\
\hline Time to volunteer & 1 & 0 & 1 & 0 & 2 \\
\hline
\end{tabular}

KICODA, Kapeeka Integrated Conservation Development Agency; NTFP, nontimber forest product.

Table 5. Personal constraints to participation as identified by interviewees.

\begin{tabular}{|c|c|c|c|c|c|}
\hline \multirow[t]{2}{*}{ Categories of Constraints } & \multicolumn{2}{|c|}{ Canada } & \multicolumn{2}{|c|}{ Uganda } & \multirow[t]{2}{*}{ Total } \\
\hline & $\begin{array}{c}\text { Men } \\
\mathrm{N}=14\end{array}$ & $\begin{array}{l}\text { Women } \\
\mathrm{N}=14\end{array}$ & $\begin{array}{c}\text { Men } \\
\mathrm{N}=17\end{array}$ & $\begin{array}{l}\text { Women } \\
\mathrm{N}=14\end{array}$ & \\
\hline Time (busy/employment/work) & 8 & 5 & 3 & 2 & 18 \\
\hline Age/health/low energy levels & 1 & 1 & 2 & 3 & 7 \\
\hline Lack of resources/equipment & 0 & 0 & 5 & 1 & 6 \\
\hline Poor communication about activities & 0 & 0 & 2 & 2 & 4 \\
\hline Lack of activities in which to participate & 0 & 0 & 2 & 1 & 3 \\
\hline Family responsibilities & 1 & 2 & 0 & 0 & 3 \\
\hline Burnout & 1 & 2 & 0 & 0 & 3 \\
\hline Timing of activities & 0 & 0 & 0 & 1 & 1 \\
\hline Literacy & 0 & 0 & 0 & 1 & 1 \\
\hline Favoritism & 0 & 0 & 1 & 0 & 1 \\
\hline Lack of knowledge/experience & 1 & 0 & 0 & 0 & 1 \\
\hline Discouragement with direction organization is taking & 1 & 0 & 0 & 0 & 1 \\
\hline Conflict of interest & 0 & 1 & 0 & 0 & 1 \\
\hline Nothing & 0 & 0 & 4 & 4 & 8 \\
\hline
\end{tabular}

Table 6. General constraints mentioned during interviews. ${ }^{\dagger}$

\begin{tabular}{|c|c|c|c|c|c|}
\hline \multirow[t]{2}{*}{ Categories of Constraints } & \multicolumn{2}{|c|}{ Canada } & \multicolumn{2}{|c|}{ Uganda } & \multirow[t]{2}{*}{ Total } \\
\hline & $\begin{array}{c}\text { Men } \\
\mathrm{N}=14\end{array}$ & $\begin{array}{l}\text { Women } \\
\mathrm{N}=14\end{array}$ & $\begin{array}{c}\text { Men } \\
\mathrm{N}=17\end{array}$ & $\begin{array}{l}\text { Women } \\
\mathrm{N}=14\end{array}$ & \\
\hline Fear men/men controlling/defer to men & 0 & 6 & 0 & 3 & 9 \\
\hline Young families/timing of activities & 0 & 8 & 0 & 1 & 8 \\
\hline Husbands leave wives out & 0 & 0 & 0 & 4 & 4 \\
\hline Small remuneration/lack of appreciation & 0 & 3 & 0 & 1 & 4 \\
\hline Physical work (e.g., mill, tree nursery) & 0 & 2 & 0 & 2 & 4 \\
\hline Lack of expertise/specific skill set & 0 & 4 & 0 & 0 & 4 \\
\hline Other (e.g., stress of being on board) & 0 & 3 & 0 & 0 & 3 \\
\hline Male-oriented activities & 0 & 0 & 0 & 2 & 2 \\
\hline No opportunities & 0 & 2 & 0 & 0 & 2 \\
\hline Conflict of interest & 0 & 2 & 0 & 0 & 2 \\
\hline Discouragement from failed project & 0 & 0 & 1 & 1 & 2 \\
\hline Poor communication about activities & 0 & 0 & 0 & 1 & 1 \\
\hline Membership fee & 0 & 0 & 0 & 1 & 1 \\
\hline
\end{tabular}


for social learning. Participation in HPCF was dominated by middle-aged, well-educated urban migrants, so that opportunities for learning disproportionately favored this social group. Reed and Davidson (2011) and Parkins and Sinclair (2014) argued that local elites tend to dominate participation in "community-based" forest management advisory committees in Canada. These migrants appear to be such an elite at HPCF. At the outset of HPCF, both men and women were engaged approximately equally in social learning activities that provided opportunities for learning and action. However, over time, men guided the CF toward an organization that focused more on logging and processing of timber. Hence, over time, gender differentiation in social learning activities became more pronounced and reinforced long-standing stereotypes about the place of women and men in forestry (Reed 2003).

The Ugandan case offered different insights about gender differentiation in social learning and forest governance. In KICODA, overall membership and participation on the executive committee was evenly split between men and women. Women constituted one-half of the executive committee, were knowledgeable and active, and reported that their voices were being heard. Their participation, then, provided access to a broader range of activities from which they could learn. However, there were some gendered differences in activities and needs in Uganda too. For example, more women participated in forest plot ownership because they wanted the plots for food cultivation; they were successful in obtaining the plots. The women were interested in accessing forestry resources, and they participated, learned, and gained benefits through a range of activities. Our results support findings by Arora-Jonsson (2010), McDermott (2009), and McDougall et al. $(2013 a, b)$ that forestry benefits and learning opportunities accrue to those who participate effectively. Although an earlier study at Budongo had found that men were twice as likely as women to participate in collaborative forest governance (Kugonza et al. 2009), we found that this situation had changed; generally, women were effective participants. This is also confirmed by Coleman and Mwangi (2013) who found that Ugandan women's participation in forest user groups was equal to men's participation. However, we found that the spaces of learning were segregated and that other axes of social differentiation were also at play.

Apart from gender, we found that literacy and education affected access to social learning opportunities for both women and men in the Ugandan case. Similarly, Lestari et al. (2015) found education levels to be positively related to participation in and learning outcomes from collaborative forest governance initiatives. In our case, women and men who could speak English and Swahili attended all seminars hosted by KICODA, but those who could not speak these 2 languages were left out. They were also highly unlikely to hold certain positions, e.g., chairman or secretary, in the executive committee that necessitated interacting in English with government officials or international nongovernmental organization employees. Because rural women in Uganda have a significantly lower literacy rate than men (according to the Uganda Bureau of Statistics [2014], literacy rates for rural areas are as follows: females, $62 \%$; males, $77 \%$ ), they may be less likely, overall, to engage in learning and governance activities. Consequently, although women and men participated in day-to-day activities, there were more opportunities for participation and learning for men than women because men were more highly educated. For example, the more influential position of chairman of a CBO had always been held by a male. This is precisely the kind of unevenness that McDougall et al. $(2013 a, b)$ were attempting to address in Nepal, and it reinforces Armitage et al.'s (2008, 2011) call for better understanding of power and marginality in social learning.

Whereas those who had fewer learning opportunities at KICODA were illiterate and less well-educated people, at HPCF those who felt marginalized were people who held different views with regard to timber harvest volumes and the values that guide HPCF's current focus, i.e., running a financially viable forestry business. Running a financially viable business meant letting go of projects like Sunshine Bay Botanicals, which required lots of effort and had a lower financial return. This business was run mostly by women. When it was closed, the expertise they had gained was not pulled into other business operations. Instead, as HPCF became more driven to gain higher profits, more women gravitated toward the society where activities focused on forest and watershed protection, ecosystem-based forest development, employment, research, and public education. This self-selection resulted in both social and spatial segregation and reproduced gender norms around resource extraction and environmental protection that have been long-standing in Canada (Reed and Varghese 2007). In summary, although social learning was occurring at HPCF and KICODA, opportunities and outcomes were not evenly shared.

\section{Gender and social learning spaces in collaborative forest governance}

We confirmed that people learned as they accessed social learning spaces during collaborative forest governance. At both HPCF and KICODA, participants reported gaining knowledge and skills related to forestry and business management, as well as conservation, through activities such as attending meetings and training seminars, networking, taking field trips, and volunteering for their forestry organizations. These findings are similar to those of other social learning scholars (e.g., Schusler et al. 2003, Brown et al. 2008, Fernandez-Gimenez et al. 2008). Furthermore, people who volunteered often were also more aware of the organization's mandate, activities, successes, failures, changes, and future plans. These findings support other scholars' findings with respect to participation in collaborative forest governance management activities in Australia, Bolivia, and Indonesia (e.g., Leys and Vanclay 2011, Biedenweg and Monroe 2013, Lestari et al. 2015); these researchers found that people who actively participated in forest management activities learned more and participated more, a kind of positive feedback loop. One could stop there and simply state that engaging in forest governance provided local community members with access to social learning opportunities and increased their capacity to participate in forest governance.

However, by examining learning outcomes against learning spaces, we found that opportunities for social learning were both socially and spatially segregated. For example, women at HPCF gravitated toward advocacy and organizing events, whereas the men leaned toward logging and business management. At KICODA, the men leaned toward forest patrols and physically demanding jobs like tree-seedling nursery preparation, whereas the women engaged in tree-seedling nursery watering, attended meetings, and supported the men. 
We found that certain constraints, for example fear of men, may have affected the spaces and strategies women chose for learning and the likelihood that women would take up influential positions. Colfer's (2013) careful review of gendered dimensions of forestry internationally suggests that domestic violence is a significant constraint for the participation of women in forestry in many countries, including Uganda. This concern raises the issue of whether women-only forums might be a useful strategy for learning and forestry governance. Arora-Jonsson's (2010) research in India and Sweden noted that such forums can be a safe place for women to discuss and address violence, and that women may need to participate in mainstream organizations and organize separately to address women's particular interests and to become effective contributors of the social learning of the organization as a whole.

\section{CONCLUSIONS}

Using cases from different country settings, we confirmed that collaborative forest governance enables participants to learn and benefit from forest management. However, by paying attention to opportunities for access, the spaces of learning, and the range of enablers, motivators, and constraints, we revealed that gender affects social learning opportunities and outcomes. More specifically, activities and outcomes for learning became spatially and socially segregated. Because of gendered access and learning spaces, the two collaborative forest governance initiatives provided more opportunities for men to participate and learn and limited learning opportunities for some groups of women. The gap, however, is not solely a gender gap. Other characteristics, such as education and literacy in Uganda and long-standing social norms in Canada, were found to be important in whether particular men or women gained opportunities for learning and influence. We also found that opportunities for social learning became more restricted for women and some men in the Canadian example over time, whereas in the Ugandan example, the opportunities for social learning were restricted for certain groups of people, e.g., illiterate men and women, right from the establishment of the initiative. If social learning is founded on or reproduces unequal opportunities to participate across the spectrum of collaborative forest governance activities, then opportunities for learning will also be uneven and the claim of collaboration will be diminished.

Our study, based on two individual cases, is necessarily incomplete. As for other multiple case studies, we did not aim to make statistical generalizations, although theoretical generalizations are possible (Yin 2009). Hence, our study is among the first to suggest that a better understanding of gender and social learning in natural resource management can help address concerns about marginalization in social learning and guide the design of future projects. Improved understanding can strengthen the capacities of communities, promote more informed interactions among participants, resolve conflicts, empower previously disadvantaged groups, and thereby help all participants become more effective managers in the long term. Shaw and Kristjanson (2014:2711) suggest that "inclusion of socially differentiated groups contributes to novel exchange and learning, helps to co-create relevant and legitimate knowledge, and build and optimize networks, which have the potential to both improve and accelerate livelihood and adaptive capacity outcomes." We share their optimism. However, our research reveals that we cannot assume that social learning opportunities are evenly shared among participants of collaborative forest governance. Social learning theorists must pay attention to the dynamics of gender and other categories of social difference as they theorize about deliberative forums and processes, and practitioners should consider gender and other axes of difference in forest-adjacent communities when designing collaborative forest governance initiatives. Future studies could investigate the effect of gender mainstreaming strategies to forest management and governance in both developing and developed countries.

Responses to this article can be read online at: http://www.ecologyandsociety.org/issues/responses. $\mathrm{php} / 8126$

\section{Acknowledgments:}

Funding for fieldwork in Canada was provided through a Social Sciences and Humanities Research Council grant. Funding for fieldwork in Uganda was provided through the John G. Bene Fellowship administered by the International Research Development Centre. Translation services in Uganda were provided through Yose Ombedra, Rehema Okusaru, and Leah Apai Gasi.

\section{LITERATURE CITED}

Agarwal, B. 2010. Gender and green governance: the political economy of women's presence within and beyond community forestry. Oxford University Press, Oxford, UK. http://dx.doi. org/10.1093/acprof:oso/9780199569687.001.0001

Armitage, D., F. Berkes, A. Dale, E. Kocho-Schellenberg, and E. Patton. 2011. Co-management and the co-production of knowledge: learning to adapt in Canada's Arctic. Global Environmental Change 21:995-1004. http://dx.doi.org/10.1016/j. gloenvcha.2011.04.006

Armitage, D., M. Marschke, and R. Plummer. 2008. Adaptive comanagement and the paradox of learning. Global Environmental Change 18:86-98. http://dx.doi.org/10.1016/j.gloenvcha.2007.07.002

Arora-Jonsson, S. 2010. Particular and wider interests in natural resource management: organizing together but separately. Scandinavian Journal of Forest Research 25(supplement 9):33-44. http://dx.doi.org/10.1080/02827581.2010.506793

Biedenweg, K., and M. Monroe. 2013. Teasing apart the details: how social learning can affect collective action in the Bolivian Amazon. Human Ecology 41:239-253. http://dx.doi.org/10.1007/ s10745-012-9535-y

Brown, H. C. P., L. E. Buck, and J. P. Lassoie. 2008. Governance and social learning in the management of non-wood forest products in community forests in Cameroon. International Journal of Agricultural Resources, Governance and Ecology 7 (3):256-275. http://dx.doi.org/10.1504/ijarge.2008.018329

Brummel, R. F., K. C. Nelson, S. G. Souter, P. J. Jakes, and D. R. Williams. 2010. Social learning in a policy-mandated collaboration: community wildlife protection planning in the eastern United States. Journal of Environmental Planning and 
Management 53(6):681-699. http://dx.doi.org/10.1080/09640568.2010 .488090

Bull, R., J. Petts, and J. Evans. 2008. Social learning from public engagement: dreaming the impossible? Journal of Environmental Planning and Management 51(5):701-716. http://dx.doi. org/10.1080/09640560802208140

Charnley, S., and M. R. Poe. 2007. Community forestry in theory and in practice: where are we now? Annual Review of Anthropology 36:301-336. http://dx.doi.org/10.1146/annurev.anthro.35.081705.123143

Coleman, E. A., and E. Mwangi. 2013. Women's participation in forest management: a cross-country analysis. Global Environmental Change 23:193-205. http://dx.doi.org/10.1016/j.gloenvcha.2012.10.005

Colfer, C. 2013. The gender box: a framework for analyzing gender roles in forest management. Occasional Paper 82. Center for International Forestry Research, Bogor, Indonesia.

Coulibaly-Lingani, P., P. Savadogo, M. Tigabu, and P.-C. Oden. 2011. Factors influencing people's participation in the forest management program in Burkina Faso, West Africa. Forest Policy and Economics 13:292-302. http://dx.doi.org/10.1016/j.forpol.2011.02.005

Cundill, G., and R. Rodela. 2012. A review of assertions about the processes and outcomes of social learning in natural resource management. Journal of Environmental Management 113:7-14. http://dx.doi.org/10.1016/j.jenvman.2012.08.021

Fernandez-Gimenez, M. E., H. L. Ballard, and V. E. Sturtevant. 2008. Adaptive management and social learning in collaborative and community-based monitoring: a study of five communitybased forestry organizations in the western USA. Ecology and Society 13(2):4. [online] URL: http://www.ecologyandsociety. org/vol13/iss $2 /$ art4/

Food and Agriculture Organization of the United Nations (FAO). 2006. Time for action: changing the gender situation in forestry. Report of UNECEF/FAO Team of Specialists on Gender and Forestry. FAO, Rome, Italy.

Harding, S. 1991. Whose science? Whose knowledge? Thinking from women's lives. Cornell University Press, Ithaca, New York, USA.

Harrop-Procter Community Forest (HPCF). 2014. HarropProcter Community Forest. HPCF, Harrop, British Columbia, Canada. [online] URL: http://www.hpcommunityforest.org/

Hayes, E., and D. D. Flannery. 2000. Women as learners: the significance of gender in adult learning. Jossey-Bass, San Francisco, California, USA.

Keen, M., V. Brown, and R. Dyball, editors. 2005. Social learning in environmental management: building a sustainable future. Earthscan, London, UK.

Kugonza, A., M. Buyinza, and P. Byakagaba. 2009. Linking local communities, livelihoods, and forest conservation in Masindi district, north western Uganda. Research Journal of Applied Sciences 4(1):10-16.

Larson, A. M., and F. Soto. 2008. Decentralization of natural resource governance regimes. Annual Review of Environmental Resources 33:213-239. http://dx.doi.org/10.1146/annurev. environ.33.020607.095522
Lebel, L., T. Grothmann, and B. Siebenhüner. 2010. The role of social learning in adaptiveness: insights from water management. International Environmental Agreements 10:333-353. http://dx. doi.org/10.1007/s10784-010-9142-6

Lestari, S., K. Kotani, and M. Kakinaka. 2015. Enhancing voluntary participation in community collaborative forest management: a case of Central Java, Indonesia. Journal of Environmental Management 150:299-309. http://dx.doi.org/10.1016/ j.jenvman.2014.10.009

Leys, A. J., and J. K. Vanclay. 2011. Social learning: a knowledge and capacity building approach for adaptive co-management of contested landscapes. Land Use Policy 28:574-584. http://dx. doi. org/10.1016/j.landusepol.2010.11.006

Mai, Y. H., E. Mwangi, and M. Wan. 2011. Gender analysis in forestry research: looking back and thinking ahead. International Forestry Review 13(2):245-258. http://dx.doi.org/10.1505/146554811797406589

McDermott, M. H. 2009. Locating benefits: decision-spaces, resource access and equity in US community-based forestry. Geoforum 40:249-259. http://dx.doi.org/10.1016/j.geoforum.2008.10.004

McDougall, C., J. Jiggins, B. H. Pandit, S. K. T. M. Rana, and C. Leeuwis. 2013a. Does adaptive collaborative forest governance affect poverty? Participatory action research in Nepal's community forests. Society and Natural Resources: An International Journal 26(11):1235-1251. http://dx.doi. org/10.1080/08941920.2013.779344

McDougall, C. L., C. Leeuwis, T. Bhattarai, M. R. Maharjan, and J. Jiggins. 2013b. Engaging women and the poor: adaptive collaborative governance of community forests in Nepal. Agriculture and Human Values 30:569-585. http://dx.doi. org/10.1007/s10460-013-9434-X

Miles, M. B., and A. M. Huberman. 1994. Qualitative data analysis: an expanded sourcebook. Second edition. Sage, Thousand Oaks, California, USA.

Mosse, J. C. 1993. Half the world, half a chance: an introduction to gender and development. Oxfam, Oxford, UK. http://dx.doi. org/10.3362/9780855987633

Muro, M., and P. Jeffrey. 2008. A critical review of the theory and application of social learning in participatory natural resource management processes. Journal of Environmental Planning and Management 51(3):325-344. http://dx.doi.org/10.1080/09640560$\underline{801977190}$

Mwangi, E., R. Meinzen-Dick, and Y. Sun. 2011. Gender and sustainable forest management in East Africa and Latin America. Ecology and Society 16(1):17. [online] URL: http://www. ecologyandsociety.org/vol16/iss1/art17/

National Forest Authority (NFA). 2003. Guidelines for implementing collaborative forest management in Uganda. NFA, Kampala, Uganda.

Nesmith, C., and P. Wright. 1995. Gender, resources, and environmental management. Pages 80-98 in B. Mitchell, editor. Resources and environmental management in Canada: addressing conflict and uncertainty. Oxford University Press, Toronto, Ontario, Canada. 
Pagdee, A., Y.-S. Kim, and P. J. Daugherty. 2006. What makes community forest management successful: a meta-study from community forests throughout the world. Society and Natural Resources: An International Journal 19:33-52. http://dx.doi. org/10.1080/08941920500323260

Parkins, J. R., and A. J. Sinclair. 2014. Patterns of elitism within participatory environmental governance. Environment and Planning C: Government and Policy 32(4):746-761. http://dx.doi. org/10.1068/c1293

Reed, M. G. 2003. Marginality and gender at work in forestry communities of British Columbia, Canada. Journal of Rural Studies 19:373-389. http://dx.doi.org/10.1016/S0743-0167(03) 00021-4

Reed, M. G. 2008. Reproducing the gender order in Canadian forestry: the role of statistical representation. Scandinavian Journal of Forestry Research 23(1):78-91. http://dx.doi. org/10.1080/02827580701745778

Reed, M. G. 2010a. Environmental governance and gender in Canadian resource industries and communities. Pages 526-553 in B. Mitchell, editor. Resource and environmental management in Canada: addressing conflict and uncertainty. Fourth edition. Oxford University Press, Don Mills, Ontario, Canada.

Reed, M. G. 2010b. Guess who's (not) coming for dinner: expanding the terms of public involvement in sustainable forest management. Scandinavian Journal of Forest Research 25 (supplement 9):45-54.

Reed, M. G., and D. Davidson. 2011. Terms of engagement: the involvement of Canadian rural communities in sustainable forest management. Pages 199-220 in B. Pini and B. Leach, editors. Reshaping gender and class in rural spaces. Ashgate, Aldershot, UK.

Reed, M. S., A. C. Evely, G. Cundill, I. Fazey, J. Glass, A. Laing, J. Newig, B. Parrish, C. Prell, C. Raymond, and L. C. Stringer. 2010. What is social learning? Ecology and Society 15(4):r1. [online] URL: http://www.ecologyandsociety.org/vol15/iss4/ $\underline{\text { resp } 1 /}$

Reed, M. G., and J. Varghese. 2007. Gender representation on Canadian forest sector advisory committees. Forestry Chronicle 83(4):515-525. http://dx.doi.org/10.5558/tfc83515-4

Richardson, K., A. J. Sinclair, M. G. Reed, and J. R. Parkins. 2011. Constraints to participation in Canadian forestry advisory committees: a gendered perspective. Canadian Journal of Forest Research 41(3):524-532. http://dx.doi.org/10.1139/x10-220

Rist, S., M. Chidambaranathan, C. Escobar, U. Wiesmann, and A. Zimmermann. 2007. Moving from sustainable management to sustainable governance of natural resources: the role of social learning processes in rural India, Bolivia, and Mali. Journal of Rural Studies 23:23-37. http://dx.doi.org/10.1016/j.jrurstud.2006.02.006

Schusler, T. M., D. J. Decker, and M. J. Pfeffer. 2003. Social learning for collaborative natural resource management. Society and Natural Resources: An International Journal 16(4):309-326. http://dx.doi.org/10.1080/08941920390178874

Senecah, S. L. 2004. The trinity of voice: the role of practical theory in planning and evaluating the effectiveness of environmental participatory processes. Pages 13-33 in S. P. Depoe, J. W. Delicath, and M.-F. Aepli Elsenbeer, editors. Communication and public participation in environmental decision making. State University of New York Press, Albany, New York, USA.

Shaw, A., and P. Kristjanson. 2014. A catalyst toward sustainability? Exploring social learning and social differentiation approaches with the agricultural poor. Sustainability 6:2685-2717. http://dx.doi.org/10.3390/su6052685

Sun, Y., E. Mwangi, and R. Meinzen-Dick. 2011. Is gender an important factor influencing user groups' property rights and forestry governance? Empirical analysis from East Africa and Latin America. International Forestry Review 13(2):205-219. http://dx.doi.org/10.1505/146554811797406598

Uganda Bureau of Statistics. 2014. National population and housing census 2014: provisional results. Uganda Bureau of Statistics, Kampala, Uganda.

Wollenberg, E., D. Edmunds, L. Buck, J. Fox, and S. Brodt. 2001. Social learning in community forests. Center for International Forestry Research, Jakarta, Indonesia.

Yadav, B. D., H. Bigsby, and I. MacDonald. 2015. The relative distribution: an alternative approach to evaluate the impact of community level forestry organizations on households. Land Use Policy 42:443-449. http://dx.doi.org/10.1016/j.landusepol.2014.08.019

Yin, R. K. 2009. Case study research: design and methods. Fourth edition. Sage, Thousand Oaks, California, USA. 